\title{
First Report on Success of Stem Cuttings on Simarouba glauca, Dc - An Easy Method for Mass Multiplication of Superior Mother Trees
}

\author{
S. Kala ${ }^{1}$, S. Reeja ${ }^{2} *$ and K. Kumaran ${ }^{3}$ \\ ${ }^{1}$ ICAR-IISWC-Research Centre, Kota-324 002, Rajasthan, India \\ ${ }^{2}$ Forest College and Research Institute, Telengana, India \\ ${ }^{3}$ Forest College and Research Institute (TNAU), Mettupalyam, Tamil Nadu - 641301, India \\ *Corresponding author
}

\begin{tabular}{|c|c|}
\hline & A B S T R A C T \\
\hline & \multirow{7}{*}{$\begin{array}{l}\text { Developing rapid and improved stem cutting propagation is essential for this promising } \\
\text { multipurpose tree borne oilseed species to achieving higher yield and income using } \\
\text { superior planting stock in commercial plantation. Present study clearly reveals the effect } \\
\text { IBA concentration on success and survival of stem cuttings. Percentage rooting and } \\
\text { primary root number differed significantly between treated and untreated cuttings. The } \\
\text { treatment }\left(\mathrm{T}_{4} \text { ) has cutting treated with IBA at } 4000 \mathrm{ppm} \text { was the best and most efficient }\right. \\
\text { hormonal concentration in simulation of higher sprouting }(52.31 \%) \text {, rooting }(45.16 \%) \text {, } \\
\text { root number per cutting ( } 4.12) \text {, root length per cutting }(6.45 \mathrm{~cm}) \text { and greater survival } \\
(42.56 \%) \text { of stem cuttings of Simarouba gluaca. However, there was significant variation } \\
\text { in height growth (shoots sprouts length) of cuttings due to IBA treatments. The results of } \\
\text { this study suggested that it is possible to produce clones of high yielding superior } \\
\text { genotypes of S.gluaca on large scale basis for use in commercial cultivation of forestry and } \\
\text { agro forestry plantations. }\end{array}$} \\
\hline Keywords & \\
\hline $\begin{array}{l}\text { Simarouba glauca, } \\
\text { Superior Mother }\end{array}$ & \\
\hline Trees, Stem & \\
\hline & \\
\hline Artic & \\
\hline $\begin{array}{l}\text { Accepted: } \\
25 \text { March } 2017 \\
\text { Available Online: } \\
10 \text { April } 2017\end{array}$ & \\
\hline
\end{tabular}

\section{Introduction}

Oilseeds and edible oils are two of the most sensitive essential commodities. India is one of the largest producers of oilseeds in the world and this sector occupies an important position in the agricultural economy. The edible oil industry is one sector in India that will see considerable reform in the foreseeable future. The country's dependence on imports can be considerably reduced by planned and judicial exploitation of tree borne oilseeds. A rainfed waste land evergreen edible oil tree, Simarouba glauca, is commonly known as 'Paradise tree' or
'Laxmitaru' belonging to family Simaroubaceae. It is derived from Greek word 'glaukos' (bluish). The specific name glauca means covered with bloom which refers to the bluish green foliage (Manasi and Gaikwad, 2011). The oil is comparable to Mahua and Sal, which is being consumed by the local people in the interior parts of the district of Bolangir, Sambalpur, Sundargarh of Orissa state (Jaipuria, 1996). The oil is largely used in the preparation of bakery products in Central America. In India too, it can be used in the preparation of vanaspathi, 
vegetable oil and/or margaraine. The oil can also be used for industrial purposes, in the manufacture of soaps, detergents, lubricants, varnishes, cosmetics, etc., Boiling the fat from the kernels and mixing with wood ashes make a crude household soap. The oilcake being rich in nitrogen (7.7 \%), phosphorus $(1.07 \%)$ and potash $(1.24 \%)$ is good organic manure. The wood of the simarouba tree is white and soft and can be used for making cheap furniture, boxes, matchsticks, yokes for oxen and as fuel. It is also insect resistant. The wood has anti-malarial and antidysenteric properties (Hiremath et al., 1996). Bark and leaves of the tree also possess similar medicinal properties (Joshi and Joshi, 2002).

S.glauca is one of the mandate species in the wasteland afforestation programme in southern India. If the oil extraction is standardized, a bulk of foreign exchange expenditure incurred on the import of edible oil can be reduced. Moreover, it can also form green belt over wastelands. This would in turn satisfy our goal of increasing the forest cover of the country in a situation where it is not possible to horizontally expand the forest area due to the inevitable demand for lands for agricultural purposes. Despite its attractive features, this tree species suffers from two drawbacks, viz., long gestation period and dioecious nature. The male and female flowers are borne on separate plants and the sex of the plant can be identified only after flowering (Hiremath et al., 1996). Apart from this, the species is reported to bear fruit when it is 6-8 years old, if it is a seedling progeny. This period, however, can be reduced to 3-4 years if grafts are planted instead of seedlings. The reduction in the long gestation period, identification of sex in the earlier stages and inducing hermaphroditism are some of the challenges to the researchers working on this tree species (Gururaja et al., 2000). The species is protrandrous, flowers annually beginning in November and continuing up to the following February/March. The plants are polygamodioecious with about 5 per cent of the population producing exclusively male flowers (staminate) and 40-50 per cent producing mainly male flowers and a few bisexual flowers (andromonoecious), the remaining 40-50 per cent only female flowers (pistillate) (Plates 1). Since there is every chance for 60:40 segregation of male to female plants in the seedling progeny, the number of fruit bearing female plants per hectare will go down after flowering, thus reducing the total yield per hectare. This maximum male to female ratio can be narrowed by top working wherein the female branches are grafted on to the male plants in the process of conversion of male to female plants. Apart from this, the gestation period can also be reduced to 3 - 4 years if grafts / cuttings could be planted instead of seedlings (Gururaja et al., 2000).

Moreover, in the species under study, the sexes are indistinguishable morphologically until the time of flowering. So, clonal propagation of superior individuals is commonly advocated as an alternative to traditional breeding strategy (Zobel, 1981) to ensure quick genetic gain. The conventional methods of propagation both sexual as well as vegetative, have problems, viz., irregular seed production, short viability, large scale consumption of seeds by birds, poor seed setting during off season, etc,. Most of the plantations are raised by direct sowing or through seedlings raised in nurseries. But, the trees exhibit considerable variation in their phenological habits. Majority of the trees in a plantation will not attain reproductive phase simultaneously. The seed production of seedling raised plants is variable. This variability in seed production as well as quality / quantity of oil can be reduced / minimized to a great extent via vegetative or clonal approach (Saini, 1998). The genotype 
of woody species is highly heterozygous and has long breeding cycles. Vegetative propagation is important for such species because their genetic improvement by breeding is slow. Clonal propagation is a highly efficient method for immediate fixing of genetic variation in contrast of the sequence of generations required of seedling propagation. Since, members of a clone are genetically uniform, they are also highly uniform phenotypically, that is, the plants will have the same appearance, size, blossoming time, fruit maturity, seed production, etc. This uniformity is the basis for the highly standardized producing practices, which are becoming the characteristics of modern silviculture (Saini, 2001).

In forestry, vegetative propagation involves the multiplication of a desired tree having superior characters (otherwise referred to as candidate plus tree). This type of propagation helps to produce plants identical in genotype with the source plant (ortet). Large genetic advances can be made in a single step by selecting a single unique superior tree from a population of seed producing trees and reproducing it asexually by vegetative propagation. The resulting population of plants has the same genotype as the original source and is called clone (ramet).

Vegetative propagation helps in the removal of biological constraints associated with seed collection, viability, storages, germination and pest. Disease resistance in large scale planting operation is achieved by utilizing disease resistant parent stock or by selecting parent stock showing wide range of adaptability. The fact that vegetative propagated trees flower earlier than seed raised ones is used in breeding and in planning seed orchard. Thus, development of clonal cuttings technique of vegetative propagation is important for conservation, multiplication of female trees for increasing seed yield per hectare, superior traits, seed orchards establishment and tree improvement work (Saini, 2001).

\section{Materials and Methods}

The present study was undertaken to optimize the stem cutting size and concentration of hormone for developing efficient stem cutting technique. With the view of fulfilling the objectives mentioned, experiments were carried out at Forest College and Research Institute, Mettupalyam (TNAU- Coimbatore), Tamil Nadu. The experimental area lies exactly at $11^{\circ} 9^{\prime} \mathrm{N}$ latitude and $76^{\circ} 56^{\prime} \mathrm{E}$ longitude. The location lies $300 \mathrm{~m}$ above MSL. The experimental area receives an annual average rainfall of $830 \mathrm{~mm}$. The mean maximum and minimum temperatures are $35.0^{\circ}$ and $20.5^{0} \mathrm{C}$ respectively. Soft wood cuttings were collected from 4-5 year old healthy and vigorous female tree Indole 3butyric acid (IBA) concentrations of 1000 , 2000, 3000, 4000 and $5000 \mathrm{ppm}$ were used along with control for comparison in the experiment. Stem cuttings of 10-15 cm long with two or three nodes were prepared and immediately treated with IBA using the quick dip method (Onio, 1987). The hormones were prepared and the single node cuttings dipped into the hormones and immediately transferred to the rooting media. The cuttings were planted in poly bags and bags were placed low cost poly tunnels inside green house. Watering was done twice daily with a knapsack sprayer. The experiment consists of four treatments and each treatment was replicated thrice with 30 cuttings per treatment. The data on various rooting parameters was recorded by observing the cutting from each replicate of each treatment after 6 weeks of treatment. The final observations on root initiation, root number per cutting, root length per cutting and survival percentage were recorded after 12 weeks of the experiment. The destructive sampling was done in five randomly selected seedlings for each treatment per replication 
and then mean was worked out. Data were subjected to analysis of variance (ANOVA) and find the significance as per the procedure devised by Panse and Sukhatme (1967). Critical difference (CD) values were calculated for comparing the treatment means at $\mathrm{p}=0.05$.

\section{Results and Discussion}

Optimization of clonal propagation technique is an important tool to raise desired genotype in a quick manner and fulfilling the aim of enhancing the desired population for commercial cultivation. Different IBA concentrations were studied to understand their effect in promoting sprouting and rooting per cent in Simarouba gluaca. Stem cuttings were assessed for percentage survival, number of roots, length of longest root and total root length. Two to three node stem cuttings of Simarouba is amenable to cloning with auxin treatment. Percentage survival of the cuttings of Simarouba gluaca showed substantial variations among the hormone concentration. The use of external hormone in stimulating root growth or length is necessary in this species. Cuttings with IBA hormones and those with 4000ppm concentration were statistically different from each other. The concentration of hormone has major effect on the cuttings either in the production of massive or long viable roots.

The data observed in the present study clearly reveals that rooting hormone IBA proved effective on root initiation and growth of adventitious roots of stem cuttings of Simarouba within 3 weeks after treatment and planting (Plate-2). After 12 weeks of that experiment, it has been observed that amongst all the six treatments tried, IBA at $4000 \mathrm{ppm}$ $\left(\mathrm{T}_{4}\right)$ was the most effective for root initiation.

The analysis of variance is presented in Table 1 , which clearly shows that all the rooting parameters viz., rooting per cent, root numbers per cutting, root length per cutting and survival per cent. It therefore revealed that treatment $\mathrm{T}_{4}-\mathrm{IBA}$ at $4000 \mathrm{ppm}$ is the best and most efficient hormonal concentration in simulation of higher sprouting $(52.31 \%)$, rooting $(45.16 \%)$, root number per cutting (4.12), root length per cutting $(6.45 \mathrm{~cm})$ and greater survival $(42.56$ $\%$ ) of stem cuttings of Simarouba gluaca.

Table.1 Effect of Indole 3-Butyric Acid (IBA) treatment on success and survival of stem cuttings in Simarouba gluaca

\begin{tabular}{|l|c|c|c|c|c|}
\hline Treatments & $\begin{array}{c}\text { Sprouting } \\
\text { \% }\end{array}$ & $\begin{array}{c}\text { Rooting } \\
\text { \% }\end{array}$ & $\begin{array}{c}\text { Number of } \\
\text { Roots }\end{array}$ & $\begin{array}{c}\text { Root length } \\
\text { cm }\end{array}$ & $\begin{array}{c}\text { Survival } \\
\text { \% }\end{array}$ \\
\hline $\mathrm{T}_{1}$ - IBA-1000PPM & 32.81 & 27.14 & 2.74 & 2.66 & 19.48 \\
\hline $\mathrm{T}_{2}$ - IBA-2000PPM & 38.46 & 30.16 & 3.13 & 3.89 & 23.14 \\
\hline $\mathrm{T}_{3}$ - IBA-3000PPM & 42.15 & 34.88 & 3.67 & 4.28 & 34.26 \\
\hline $\mathrm{T}_{4}$ - IBA-4000PPM & 52.31 & 45.16 & 4.12 & 6.45 & 42.56 \\
\hline $\mathrm{T}_{5}$-IBA-5000PPM & 45.26 & 37.21 & 3.97 & 5.01 & 38.91 \\
\hline $\mathrm{T}_{6}$ - Control & 20.18 & 5.19 & 1.17 & 1.91 & 0 \\
\hline SE.d & $\mathbf{2 . 6 7}$ & $\mathbf{3 . 3 8}$ & $\mathbf{0 . 2 4}$ & $\mathbf{0 . 3 6}$ & $\mathbf{3 . 5 4}$ \\
\hline C.D (p=0.05) & $\mathbf{5 . 3 6}$ & $\mathbf{6 . 5 4}$ & $\mathbf{0 . 4 9}$ & $\mathbf{0 . 7 5}$ & $\mathbf{6 . 9 9}$ \\
\hline
\end{tabular}



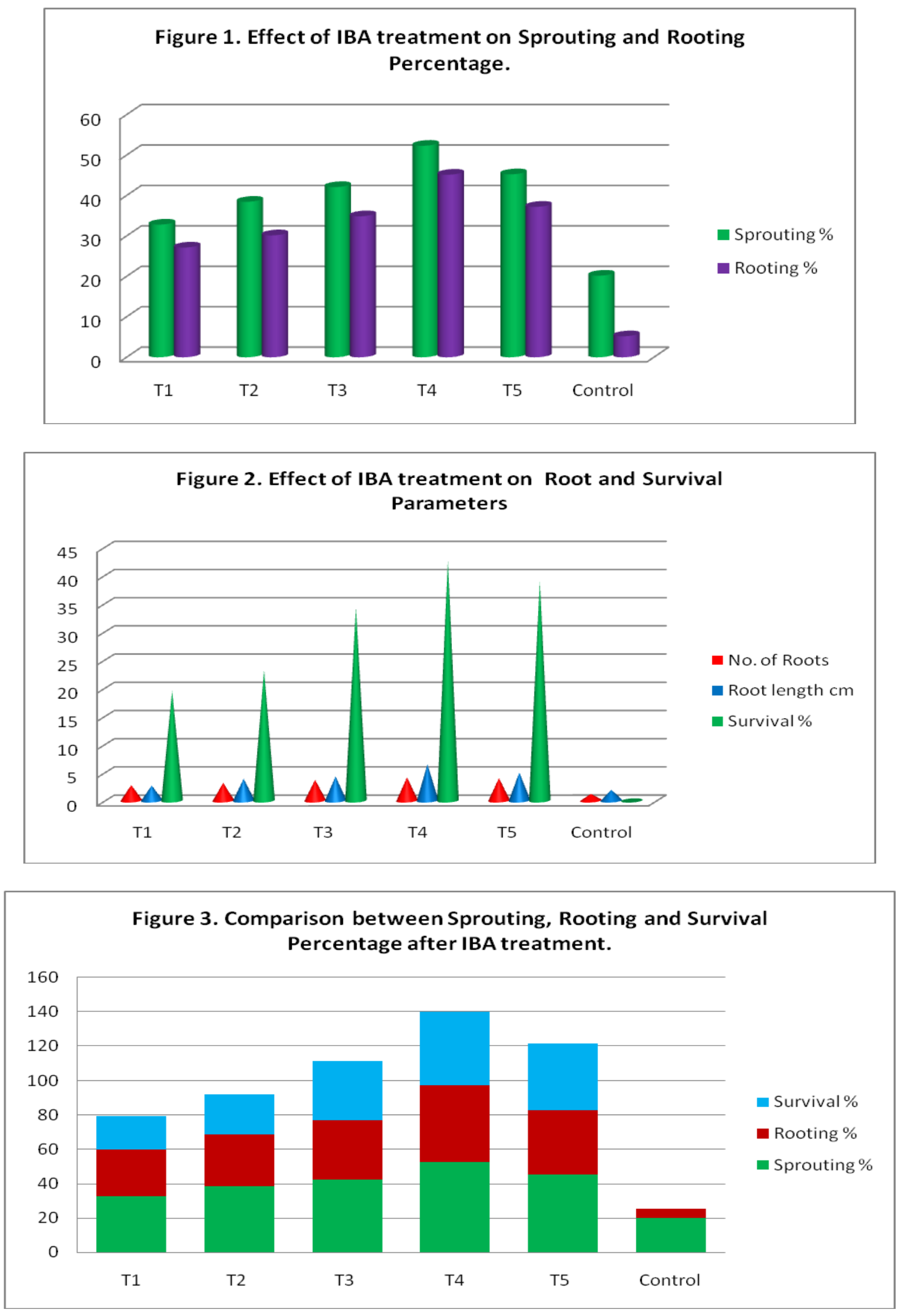
Plate.1 Different Sex forms in Flowers of Simarouba gluaca, DC

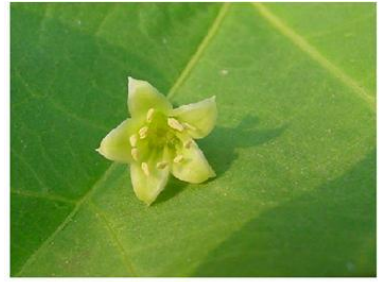

Male flower

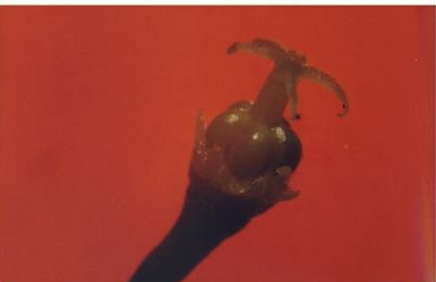

Gynoecium of female flower

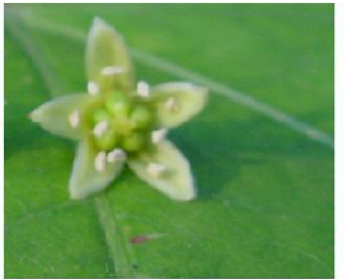

Bisexual flower

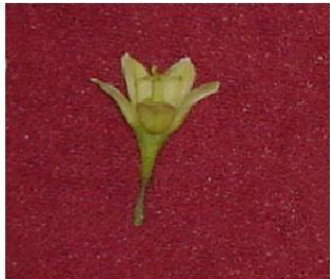

Female flower

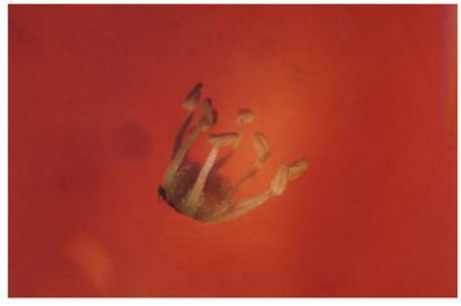

Androecium of Male flower

Plate.2 Success of Stem cutting propagation in Simarouba gluaca

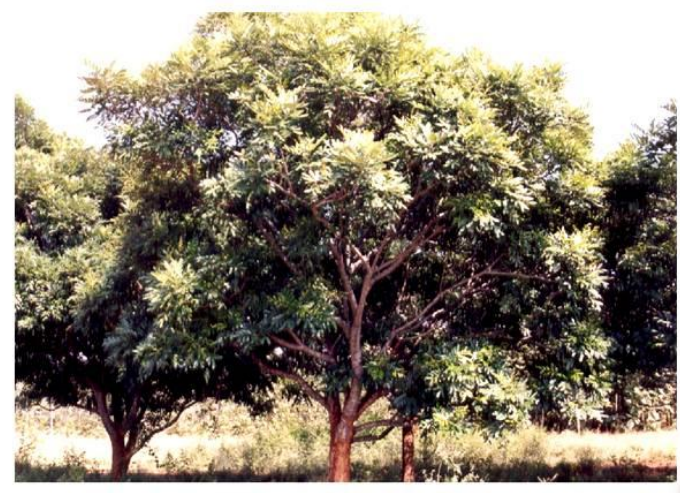

Mother Trees of Simarouba gluaca

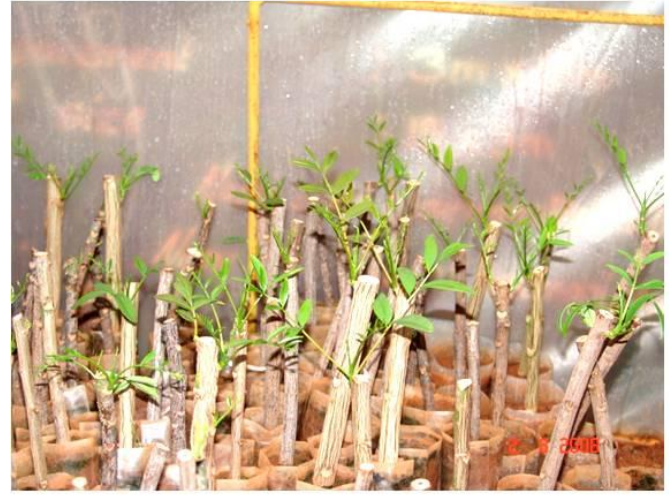

Stem cutting of Simarouba gluaca

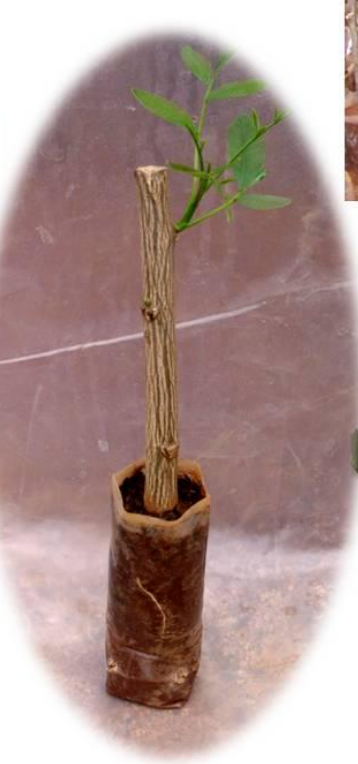

Sprouted stem-cutting at 45 days

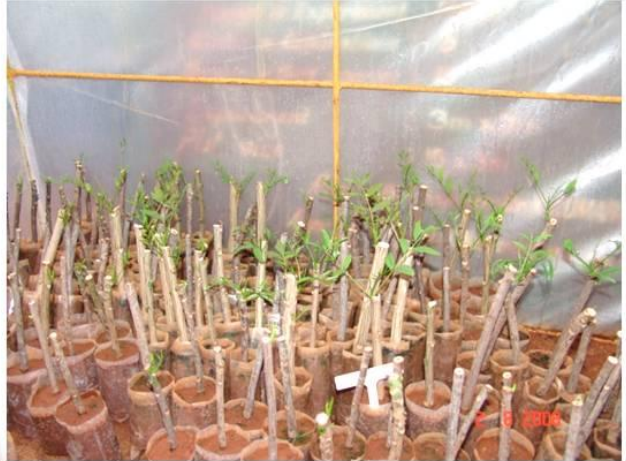

\section{Stem-cutting treated With IBA- 4000 ppm}

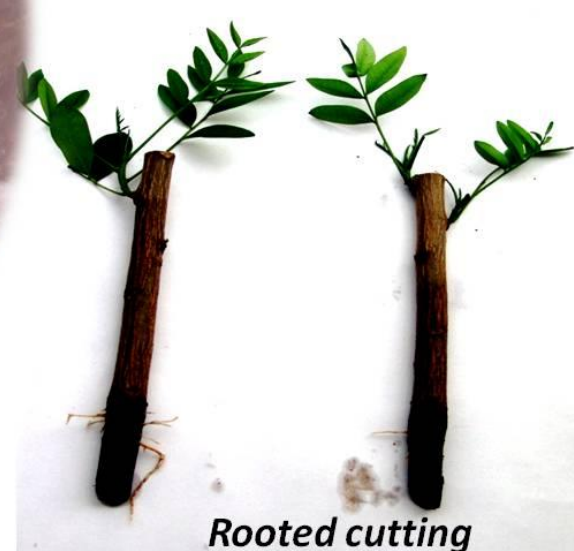

Rooted cutting With IBA- 4000 ppm 
Moderate concentration of IBA at $4000 \mathrm{ppm}$ could be better than higher (IBA at 5000 ppm) and lower (IBA at 1000 and 20000 ppm) concentrations. However, IBA 5000 ppm also showed the similar effect on root initiation as that of IBA 4000 ppm. Cuttings dipped in IBA 4000 ppm showed significantly higher root length and number of roots at 3 and 4 weeks after treatment when compared to IBA 5000 ppm. Similarly, IBA 1000, 2000, 3000 ppm also had shown significant amount of rooting at 25 and 35 days after treatment when compared to control. Further increasing IBA concentration may hinder rooting percent and root numbers. Hence, IBA 4000 ppm is an ideal concentration for enhancing rooting of stem cutting with short period of time. Similar kind of results was obtained in Bixa orellana (Kala and Kumaran, 2015) who opined that treating stem cuttings treated with IBA 4000 ppm promoted rooting and increased the number of roots.

The shooting was observed and but rooting was not initiated in $\mathrm{T}_{6}$ (control). So in order to induce the profuse rooting, treatment of cuttings with IBA at $4000 \mathrm{pm}$ in particular is found to be beneficial. The exogenous application of hormones had been reported earlier in Casuarina equisetifolia and Gmelina arborea (Parthiban et al., 1999) Ceiba pendandra (Rajendran et al., 2000), Bixa orellana (Kala and Kumaran, 2015) and Zanthoxylum alatum (Daudi et al., 2016).

This initial research study results evidenced and supported the scope for producing stem cutting method of clonal propagules in Simarouba gluaca. The introduction of small quantity of hormone enhanced the initial of rooting in this species. The cuttings require a medium well drained rooting medium for good drainage and sufficient spaces to prevent water logging and subsequent rooting of the cuttings. Although study indicated that semihardwood cutting treated with IBA 4000 ppm could respond well in terms rooting and initial success at nursery conditions.

\section{Acknowledgement}

The authors are thankful to the Indian Council of Agricultural Research - New Delhi for providing financial grants for carrying out the research work.

\section{References}

Armour, R.P.,(1959): Investigations On Simarouba glauca DC. In El Salvador. Economic Botany, San Salvador.

Daudi.P, K. Singh, B.V. Pandey (2016): Propagation techniques of Zanthoxylum alatum Roxb. (A Himalayan Toothache Shrub). Current science, Vol. 110, No. 1 January 2016, pp.30-33.

De Sola and Francisco.,(1956): Notes on the aceituno tree (Simarouba glauca DC.) and its adaptation as a vegetable oil crop. Ceiba, 4: 351-358.

Gururaja Rao, M.R., T.B. Basavaraja and Syamsunder Joshi., (2000): An early flowering variant in seedling progeny of Simarouba glauca. Indian J. For., 23(4): 444-445.

Hiremath, S.R., S. Joshi, K.G. Shambulingappa, K.M. Channakrishnaiah, Chikkadeviah, D.P. Jagannath and K. Seenappa.,(1996): Floral biology of Simarouba glauca DC, an oil seed tree. Journal of Oil Seeds Research, 13(1): 93-96.

Jaipuria,, M.K., (1996): Trial of exotic species in Bihar Simarouba glauca. Indian J. For., 19(1): Pp:58-68.

Joshi Syamsundar, Shanta Joshi, K.G. Shanbulingappa and K. Channakrishnaiah. (1996). Preliminary studies on Simarouba glauca DC. A promising oil seed tree. Crop Res., 11: 385-390.

Joshi, S., Joshi, S.,(2002): OIL TREELaxmitaru Simarouba glauca, PP: 
86.University of Agricultural sciences, Bangalore and Indian council of Agricultural Research, New Delhi, India.

Kala, S., and K. Kumaran (2015): Improved clonal propagation technique for mass multiplication of bixa orellana, L. Indian Forester, 141 (3): pp.279-284.

Kumaran, K., J. Sundersingh Rajapandian and K.S. Neelakantan.,(2001): Personal communication, paradise tree. Forest College and Research Institute, Mettupalayam. Pp. 4 ..

Manasi P. S. and Gaikwad D. K., (2011). A Critical Review on Medicinally Important Oil Yielding Plant Laxmitaru (Simarouba glauca DC.) J. Pharm. Sci. \& Res. Vol.3 (4), Pp:1195-1213.

Onio., (1987): Effect of auxins on the rooting of stem cuttings of Terminalia superba (Engl. and Diels). In: Oguntala A.B. (ed.). The role of forestry in a depressed economy. Proceedings of the $17^{\text {th }}$ Annual Conference of the Forestry Association of Nigeria, 6-10 December 1987, Ikeja, Lagos State, Nigeria, pp. 43-48,1987.

Panse, V.G. and P.V. Sukhatme (1978): Statistical methods for agricultural workers. ICAR Publication, New Delhi. $327 \mathrm{pp}$.

Parthiban, K.T., Surendran,., Murugesh, M and Buvaneswaran, C. (1999):Vegetative propagation of few multipurpose tree species using stem cutting. In: Advances in Horticulture and Forestry, 6 (199). Scientific Publishers, Jodhpur, pp 175-178.

Patel, D.P., V.D. Verma, T.R. Loknathan, K.L. Bhatt and J.B. Mishra., (1997): Simarouba glauca - a non traditional oil source. Indian Farming, 47(1): 7-9.

Rejendran, P, Dasthagir, M.G, Yassin, M.M and Divakara, B.N. (2002): Vegetative propagation of ceiba pentandra (Linn) Gaertn. By stem cuttings. Indian journal of Agroforestry, 4 (1):67-70.

Saini, R.P. (1998). Vegetative propagation. Silviculture (Hills) division, West Bengal. Bulletin No. 1 of 1998-99. p. 1.

Saini, R.P.(2001): Vegetative propagation in silviculture (Hills) division, Darjeeling (West Bengal). Indian Forester, 127(4): 389-408.

Zobel, B.,(1981): Proc. South For. Tree Improvement Conf. 16 ${ }^{\text {th }}$ Blacksburg, Virginia. Pp. 144-150.

\section{How to cite this article:}

Kala, S., S. Reeja and Kumaran, K. 2017. First Report on Success of Stem Cuttings on Simarouba glauca, Dc - An Easy Method for Mass Multiplication of Superior Mother Trees. Int.J.Curr.Microbiol.App.Sci. 6(4): 2646-2653. doi: https://doi.org/10.20546/ijcmas.2017.604.308 